\title{
Condução docente como fundamento da experiência positiva com metodologias ativas em uma residência multiprofissional
}

\author{
Leonardo Carnut, Cristina Albuquerque Douberin, Tereza Natalia Bezerra de Lima
}

\begin{abstract}
Resumo
Introdução: Por toda crítica à educação bancária e aos métodos pedagógicos tradicionais, atualmente, nos cursos de saúde tem se percebido uma maior incorporação de outras metodologias, mais orientadas aos estudantes e seus ritmos de aprendizagem, provocando o professor e seu 'trabalho docente' a sair do 'lugar comum', especialmente naqueles que foram formados pelo método tradicional e insistem em reproduzi-lo. Neste sentido, o uso das metodologias ativas de ensino-aprendizagem vem sendo amplamente reconhecido na área da saúde por permitir maior autonomia na conquista do conhecimento pelo educando e proporcionar uma maior possibilidade de construção do pensamento crítico-reflexivo. Estas características chamam a atenção por se coadunarem com o 'perfil dos egressos' preconizados nas Diretrizes Curriculares Nacionais em todas as graduações da área da saúde. Contudo, os docentes que aderem ao uso das metodologias ativas, ainda que seduzidos pela perspectiva da inovação, são tomados pelo sentimento de 'insegurança' gerando uma contradição entre a 'ansiedade da inexperiência' e a 'tentativa da execução bem-sucedida' podendo gerar uma percepção equivocada nos estudantes sobre a efetividade destes métodos. É a partir desta situação, que corriqueiramente acontece nas salas de aula dos cursos de saúde que vem emergindo a discussão sobre a capacidade de condução docente no uso das metodologias ativas como práticas inovadoras no ensino em saúde assim como o perfil em sala de aula que os docentes podem produzir para conduzir essas metodologias sem descaracterizar seus princípios e sem dirimir suas potencialidades. Objetivo: Assim, este estudo visou analisar a percepção discente sobre os pontos positivos (potencialidades) da condução pelo docente do uso das metodologias ativas de ensino- aprendizagem em um curso de residência multiprofissional levando-se em consideração a pluralidade do perfil profissional e como este pode ser um desafio a ser enfrentado no processo ensino-aprendizagem em saúde. Percurso Metodológico: Para tanto, desenhou-se um percurso metodológico baseado em uma pesquisa-ação, qualiquantitativa, com foco na investigação de percepção vivencial dos discentes sobre uma estratégia didática adotada. O cenário pedagógico foi o módulo de 'Sociologia e Antropologia da Saúde', com carga horária total de 24 horas, ministrada na Residência Multiprofissional em Saúde Coletiva (com ênfase em Gestão de Redes de Atenção à Saúde) da Universidade de Pernambuco (UPE) em outubro de 2015 e tendo quarenta e cinco (45) estudantes como sujeitos partícipes dessa atividade. Ao decorrer do módulo, os residentes trabalharam os conteúdos através de uma abordagem pedagógica mista, baseada na mescla de diversos métodos ativos, incluindo tempestade de ideias, leituras coletivas, questões norteadoras, mapas conceituais, fichamentos coletivos e seminários dialogados. Ao final do módulo, realizou-se uma entrevista não-estruturada com os estudantes sobre a experiência vivenciada com a finalidade de captar a percepção dos residentes sobre o método executado. Pediu-se aos residentes que dissertassem sobre o seguinte tópico: "Coloque os pontos positivos que você percebe no módulo e na sua condução pelo professor" e os estudantes produziram textos em resposta a essa demanda de forma livre e aberta. A partir dos textos elaborados pelos estudantes, analisou-se o material produzido através da Análise de Conteúdo Clássica, do tipo Análise Frequencial (com uso de 'proposições' como Unidades Textuais (UT) de análise) e elegendo como suporte comparativo a experiência empírica já sistematizada por Anjos e colaboradores (2013) sobre a percepção de estudantes sobre o uso de metodologias ativas.
\end{abstract}


ISSN 2179-6750

Resultados: Decompôs-se os textos produzidos pelos estudantes em 205 Unidades de Texto (UT) (205 proposições) que puderam ser categorizadas em 17 áreas temáticas de significados correlatos construídas através de aproximação léxico-semântica. Por ordem de frequência no decorrer dos textos, foi possível identificar que as temáticas se organizam nas seguintes categorias: "Clareza e domínio do professor na abordagem de conteúdos" 13,65\% (28); "Relacionamento professor-aluno" 11,21\% (23); e "Utilização em formas de discussão" 10,73\% (22); "Disponibilização de textos e incentivo à realização de leituras" 9,26\% (19); "Estímulo à construção de pensamento" 8,78\% (18); "Construção e consolidação dos conhecimentos" 8,78\% (18); "Importância da metodologia ativa" $5,85 \%$ (12); "Presença de didática" 5,85\% (12); "Estímulo/incentivo às atividades em grupo ou equipe" 5,85\% (12); "Perfil profissional do professor" 5,36\% (11); "Contribuição para uma boa formação" 3,90\% (8); "Dinamicidade da aula" 3,90\% (8); "Tipo de linguagem utilizada em sala de aula" 1,95\% (4); "Realização de planejamento" 1,95\% (4); "Caracterização da aula" 0,97\% (2); "Diálogo da/na aula" 0,97\% (2) e "Apoio nos trabalhos" 0,97\% (2). De acordo com os conteúdos identificados é possível perceber que os estudantes relatam quase que um 'perfil de competências' que o professor precisa deter para tornar a prática pedagógica com metodologias ativas uma experiência positiva, especialmente quando se trata de uma turma com características multiprofissionais. Anjos e colaboradores (2013) já apontavam que o comprometimento docente no processo pedagógico no uso de metodologias ativas é essencial e quando este comprometimento não ocorre pode provocar falhas na conduta dos professores. Este problema de condução proporciona que uma parte significativa dos discentes apresentam-se insatisfeitos parcial ou completamente com o uso das metodologias ativas adotadas, negando-as ou afirmando que precisam ser aprimoradas. O presente estudo demonstra que os residentes descrevem diversas características relacionais que sustentam o sucesso da experiência pedagógica e que apontam para um conjunto de ações que refletem o compromisso do docente no uso dos métodos ativos e sua segurança durante a execução. Conclusões: Parte significativa dos conteúdos identificados nos textos dos estudantes apontam para condução do professor como elemento essencial no uso dessa metodologia pedagógica especialmente no que se refere à clareza e domínio na abordagem dos conteúdos via métodos ativos, na relação mais horizontalizada entre professor e aluno assim como na utilização das discussões como forma de construção do conhecimento. Sem que haja o investimento dos docentes nesse perfil é muito provável que a experiência com o uso de metodologias ativas não logre êxito, e, assim, a condução docente fique prejudicada a ponto de gerar um descrédito nas metodologias ativas como práticas de ensino-aprendizagem apropriadas para grupos multiprofissionais. Para que a maior parte dos estudantes se sinta satisfeita e relate o uso das metodologias ativas como uma experiência pedagógica positiva se faz necessário um processo de condução do método por professores que apresentem a possibilidade de construção desse saber experiencial minimamente constituído.

Descritores: Internato e Residência, Ensino, Educação Superior, Docentes 